Scotland's Referendum and the Media 



\section{Scotland's Referendum and the Media}

National and International

Perspectives

\section{Edited by Neil Blain and David Hutchison with Gerry Hassan}


Edinburgh University Press is one of the leading university presses in the UK. We publish academic books and journals in our selected subject areas across the humanities and social sciences, combining cutting-edge scholarship with high editorial and production values to produce academic works of lasting importance. For more information visit our website: www.edinburghuniversitypress.com

(C) editorial matter and organisation Neil Blain and David Hutchison with Gerry Hassan, 2016

(C) the chapters their several authors, 2016

Edinburgh University Press Ltd

The Tun - Holyrood Road

12 (2f) Jackson's Entry

Edinburgh EH8 8PJ

Typeset in 10/12 Goudy Old Style by Servis Filmsetting Ltd, Stockport, Cheshire, and printed and bound in Great Britain by CPI Group (UK) Ltd, Croydon CR0 4YY

A CIP record for this book is available from the British Library

ISBN 9780748696581 (hardback)

ISBN 9780748696598 (paperback)

ISBN 9780748696604 (webready PDF)

ISBN 9780748696611 (epub)

The right of the contributors to be identified as authors of this work has been asserted in accordance with the Copyright, Designs and Patents Act 1988 and the Copyright and Related Rights Regulations 2003 (SI No. 2498). 